\title{
Mutation analysis of the LCE3B/LCE3C genes in Psoriasis
}

\author{
Eliecer Coto ${ }^{1,4^{*}}$, Jorge Santos-Juanes ${ }^{2,4}$, Pablo Coto-Segura ${ }^{2}$, Marta Díaz $^{1}$, Javier Soto ${ }^{2}$, Rubén Queiro ${ }^{3}$, \\ Victoria Alvarez ${ }^{1}$
}

\begin{abstract}
Background: An association between a common deletion comprising the late cornified envelope LCE3B and LCE3C genes (LCE3C_LCE3B-del) and Psoriasis (Ps) has been reported. The expression of these LCE genes was induced after skin barrier disruption and was also strong in psoriatic lesions. The damage to the skin barrier could trigger an epidermal response that includes the expression of genes involved in the formation of skin barrier.

Methods: We determined the LCE3C_LCE3B-del genotype in 405 Ps patients and 400 healthy controls from a Northern Spain region (Asturias). These patients and controls were also genotyped for the rs4112788 single nucleotide polymorphism, in strong linkage disequilibrium with the LCE3C_B cluster. The LCE3B and LCE3C gene variant was determined in the patients through SSCA, DHPLC, and direct sequencing.

Results: Allele and genotype frequencies did not differ between patients and controls for the rs4112788 and LCE3C_LCE3B-del polymorphisms. However, del/del homozygotes were significantly higher among patients with chronic plaque type Ps who did not develop arthritis $(p=0.03 ; \mathrm{OR}=1.4 ; 95 \% \mathrm{Cl}=1.03-1.92)$. The analysis of the coding sequence of LCE3B and LCE3C in the patients who had at least one copy of this showed that only one patient has a no previously reported LCE3B variant (R68C).

Conclusion: Our work suggested that homozygosity for a common LCE3C_LCE3B deletion contributes to the risk of developing chronic plaque type Ps without psoriatic arthritis. Our work confirmed previous reports that described an association of this marker with only skin manifestations, and supported the concept of different genetic risk factors contributing to skin and joint disease.
\end{abstract}

\section{Background}

Psoriasis (Ps) is a chronic hyperproliferative inflammatory disease of the skin that affects approximately $2 \%$ of individuals [1]. Ps is characterized by an abnormal keratinocyte proliferation and differentiation, and the infiltration of immunocompetent cells in the epidermis and dermis [2]. Psoriatic arthritis (PsA) is a chronic inflammatory joint disease which occurs in $7-42 \%$ of Ps patients [3]. Ps susceptibility involves environmental and genetic factors [4]. The genetic component is partly explained by its association to the HLA-Cw6 allele, that defines the PSOR1 locus on chromosome 6p21 [5,6]. Genome-wide association studies (GWA) and familybased studies have identified other Ps associated genes,

\footnotetext{
* Correspondence: eliecer.coto@sespa.princast.es

${ }^{1}$ Genética Molecular, Hospital Universitario Central Asturias-Servicio de Salud del Principado de Asturias, Oviedo, Spain
}

and some of them encode proteins involved in the immune response and expressed in keratinocytes and $\mathrm{T}$ cells [7-10].

Copy number variants (CNVs) are an important source of genetic variability, and contribute to the susceptibility to several diseases [11]. A candidate gene approach identified a higher copy number of the betadefensin cluster as a risk factor for Ps, and a recent genome-wide CNV analysis identified the association of Ps with a deletion comprising the $L C E 3 B$ and $L C E 3 C$ genes (LCE3C_LCE3B-del) $[9,12]$. These genes encode members of the late cornified envelope (LCE), and are in the region that contains the PSORS4 locus on chromosome 1q21 $[13,14]$. The mRNA for several LCE3 genes was absent in normal skin, but its expression was induced after skin barrier disruption and was also strong in psoriatic lesions [9]. In this way, the damage to the skin barrier could trigger an epidermal response that includes 
the expression of genes involved in the formation of skin barrier, such as those in the LCE cluster. The impaired response in individuals homozygous for the LCE3C_LCE3B-del could explain the higher risk for Ps conferred by this genotype. The reported lack of association between the LCE3C_LCE3B-del and psoriatic arthritis suggested that this was a risk factor for only skin disease, supporting the concept that different genetic factors contributed to skin disease and joint manifestations $[15,16]$.

Here, we report the results of a case-control study for the association between the LCE3C_LCE3B-del and Ps. In addition, we searched for DNA variants in the coding sequences of $L C E 3 C$ and $L C 3 B$ in Ps patients.

\section{Methods}

\section{Patients and controls}

All the patients and controls were Spanish Caucasians from the region of Asturias (Northern Spain, total population 1 million). A total of 405 non-related patients with Ps (mean age $47 \pm 16$ years; $54 \%$ men) were recruited by Dermatologists from Hospital Universitario Central Asturias (HUCA) and Hospital A. Buylla-Mieres. Ps was diagnosed based on clinical findings, and the Psoriasis Area and Severity Index (PASI) was determined. Patients who were diagnosed with arthritis prior to Ps were not included in the study. The disease was considered as severe in patients with a PASI score $=10$ [17]. Patients were considered to have "early onset" psoriasis if the onset of the disease was at any age $\leq 40$ years, and "late onset" psoriasis if the onset was $>40$ years. Patients were considered to have "familial" psoriasis if they had at least one first- or second-degree relative affected by the condition. Patients with PsA were assessed by a rheumatologist according to the criteria of Moll and Wright [18]. All the patients were followed for $>2$ years after psoriasis was diagnosed (mean follow-up, $17 \pm 14$ years). Table 1 summarizes the main characteristics of the patients.

The control group comprised 400 non-related healthy individuals (mean age $49 \pm 16$ years; range $18-85$ years; $55 \%$ men) recruited through the Dermatology Department (Hospital staff and healthy spouses of patients) and the HUCA-Blood Bank. The study was approved by the Ethical Committee of HUCA, and all the individuals gave their informed consent to participate.

\section{LCE3C_LCE3B-del genotyping}

We determined the LCE3C_LCE3B-del genotype following a three-primer polymerase chain reaction (PCR) assay, as reported [9]. Genomic DNA from patients and controls was PCR-amplified in a single tube containing each of three primers: LCE3F (forward), LCE3CR (reverse), and LCE3CR2D (reverse). Ten $\mu \mathrm{l}$ of each reaction were electrophoresed on $2 \%$ agarose gels, and the
Table 1 Main characteristics of the $\mathbf{4 0 5}$ patients with Psoriasis

\begin{tabular}{|c|c|}
\hline Gender (male/female) & $210(54 \%) / 195(46 \%)$ \\
\hline Mean age (years $\pm S D)^{*}$ & $47 \pm 16$ \\
\hline \multicolumn{2}{|l|}{ Type of psoriasis } \\
\hline Vulgaris & $324(80 \%)$ \\
\hline Palmoplantar & 49 (12\%) \\
\hline Guttate & $16(4 \%)$ \\
\hline other & $16(4 \%)$ \\
\hline Cw6+ & $158(39 \%)$ \\
\hline $\begin{array}{l}\text { Affected relatives } \\
\text { (familial Ps) }\end{array}$ & $219(54 \%)$ \\
\hline Early-onset psoriasis $^{\#}$ & $243(60 \%)$ \\
\hline Mean age $(\text { years } \pm S D)^{*}$ & $34 \pm 14$ \\
\hline Cw6+ & $124(51 \%)$ \\
\hline Late-onset psoriasis" & $162(40 \%)$ \\
\hline Mean age (years $\pm S D)^{*}$ & $59 \pm 9$ \\
\hline Cw6+ & $34(21 \%)$ \\
\hline Non-severe Ps (PASI < 10)* & $243(60 \%)$ \\
\hline Severe Ps $(P A S I \geq 10)^{*}$ & $162(40 \%)$ \\
\hline Arthritis & 89 (22\%) \\
\hline Non-Arthritis & $316(78 \%)$ \\
\hline
\end{tabular}

"Early onset psoriasis, age $\leq 40$ years; Late onset psoriasis, age $>40$ years. *SD, standard deviation; PASI, Psoriasis Area and Severity Index.

non-deletion allele visualized as a fragment of $240 \mathrm{bp}$ (LCE3CF-LCE3CR product), and the deletion as a fragment of 199 bp (LCE3CF-LCE3CR2D product).

\section{SNP rs412788 genotyping}

SNP rs4112788 (T/C) was genotyped in patients and controls through restriction enzyme digestion of a PCR fragment generated with primers Fwd: 5'GTAGAGACTAACCATATAACATGTGG (forward) and Rvs: 5'GAAAACCTTTAGACTACAATTAAAAGC (reverse) (PCR annealing, $55^{\circ} \mathrm{C}$ ). The last nucleotide in Rvs has a mismatch to create a site for the restriction enzyme MspI on PCR fragments with the C allele. After digestion with this enzyme and electrophoresis on $3 \%$ agarose gels, alleles were visualized as bands of $215 \mathrm{bp}(\mathrm{T})$ or $190+25$ bp (C).

A total of 150 patients and 150 controls (representing at least 50 of the three PCR-RFLP genotypes) were also genotyped with a custom Taqman assay for SNP rs4112788 (assay id C_31910050_10) in a real time PCR Step One (ABI).

To determine the accuracy of the two genotyping methods we sequenced 20 individuals with each of the 
three genotypes. A $330 \mathrm{bp}$ fragment was amplified with primers Fwd (see above) and 5' GACTCTCCAAGGGACATTTTTTGT (reverse) (annealing at $56^{\circ} \mathrm{C}$ ), and both strands were sequenced.

\section{LCE3B/3C mutation screening}

We amplified the $L C E 3 B$ and $L C E 3 C$ coding sequences in the patients with primers designated from the reference sequences http://www.ensembl.org; ENSG00000187238 for $L C E 3 B$; ENSG00000187238 for $L C E 3 C$ ). The full transcripts encode proteins of 96 amino acids are contained in single exons. The $L C E 3 B$ fragment was $422 \mathrm{bp}$ long and was amplified with primers GGGCTTCATAAAACCATTTGTAGAG (forward) and TTTCCTCTAAAGTCGCTTGTCTCA (reverse) (annealing, $63^{\circ} \mathrm{C}$ ). The $L C E 3 C$ was a $448 \mathrm{bp}$ fragment amplified with primers GGTCTGAGGGTTCTGTGCTCA (forward) and TCTGGAAAAGCATGCATCAGG (reverse) (annealing, $62^{\circ} \mathrm{C}$ ).

To search for DNA variants, a total of 45 LCE3B and $L C E 3 C$ fragments (corresponding to 15 ins/ins patients and 15 ins/del patients) were sequenced. PCR fragments from all the patients were also subjected to single strand conformation analysis (SSCA), and fragments with atypical SSCA electrophoretic patterns were sequenced to characterize the nucleotide changes [19]. These PCR fragments were also subjected to Denaturing High Performance Liquid Chromatography (DHPLC) in a Varian Helix System and with a linear binary gradient created with buffers Varian Helix A (triethylammonium amine TEAA) and B (TEAA+25\% acetonitrile; http://www.varianinc.org), and the nucleotide changes responsible for the different elution profiles were identified by sequencing the corresponding PCR fragments. The DHPLC elution temperatures and buffer gradients for the PCR fragments were calculated with the DHPLC Melt Program http://insertion.stanford.edu/melt.html, and are available upon request to the corresponding author.

\section{Statistical analysis}

Data management and statistical analysis were carried out using SPSS for windows (release 15.0; SPSS, Inc). Differences of the allele frequencies between the groups were assessed using the $\chi^{2}$ test. Odds ratios (OR) and their $95 \%$ confidence intervals $(\mathrm{CI})$ values were also calculated. The Student's $t$ test was used to compare the quantitative data between the groups. A p $<0.05$ was considered as statistically significant. The power of the study for each frequency comparison was calculated online http://statpages.org/proppowr.html.

\section{Results}

\section{LCE3C_3B del frequencies}

We determined the genotype for the common LCE3C_LCE3B CNV in 405 Ps patients and 400 controls (Figure 1). Genotype and allele frequencies for the LCE3C_LCE3B-del in patients and controls are summarized in table 2 . The observed genotype frequencies did not differ from those expected under the Hardy-Weinberg equilibrium. We did not find significant differences for the genotype and allele frequencies between the controls and total patients. The del/del frequency was higher among patients with Ps vulgaris $(\mathrm{n}=324)$ compared to controls ( $42 \%$ vs. $36 \%$ ) although the difference did not reach statistical significance $(\mathrm{p}=0.08$; $\mathrm{OR}=$ $1.30,95 \mathrm{CI}=0.96-1.76$ ).

Because a previous study reported a negative association between the LCE3C_LCE3B-del and psoriatic arthritis, we compared the genotype frequencies between controls and patients who did not develop arthritis $(n=274)$. The frequency of del/del was significantly higher in this group compared to controls (44\% vs. $36 \% ; \mathrm{p}=0.03 ; \mathrm{OR}=1.4(1.03-1.92)$. However, the number of patients/controls was insufficient to reach a power of 80 . At a significance level of $p=0.05$, with $\mathrm{del} / \mathrm{del}$ frequencies of 0.36 in controls and 0.44 in

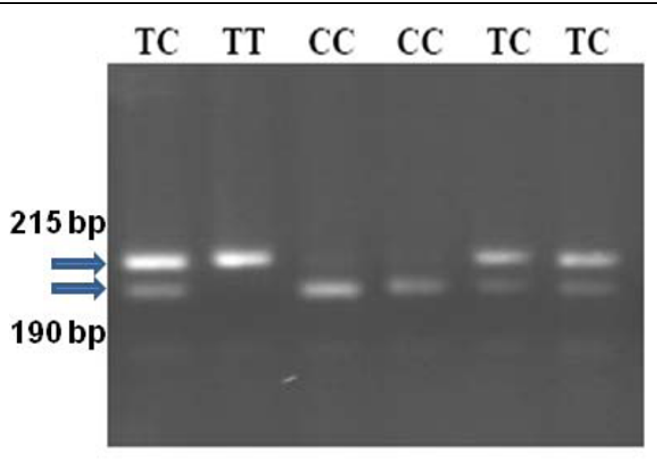

rs 4112788

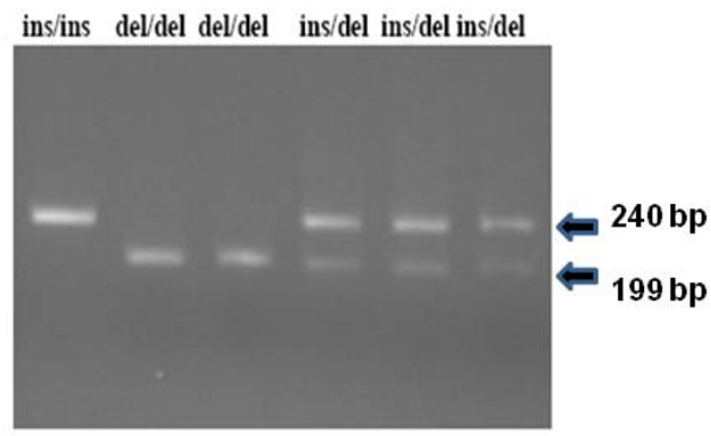

LCE3B_LCE3C ins/del

Figure 1 PCR-RFLP genotypes of rs4112788 (right) and LCE3B_3C ins/del genotypes (right). The rs4112788 alleles were visualized as bands of $215 \mathrm{bp}(\mathrm{T})$ and $190+25 \mathrm{bp}$ (C). The LCE3B_3C insertion and deletion alleles were visualized as PCR fragments of 240 bp and 199 bp. 
Table 2 Genotype and allele frequencies for the LCE3C_LCE3B-del (parentheses indicate frequencies)

\begin{tabular}{|c|c|c|c|c|c|}
\hline & \multicolumn{3}{|c|}{ LCE3 genotypes } & \multicolumn{2}{|c|}{ Alleles } \\
\hline & II & ID & $\mathrm{DD}$ & D & 1 \\
\hline $\begin{array}{l}\text { Controls } \\
(n=400)\end{array}$ & $\begin{array}{c}60 \\
(15)\end{array}$ & $\begin{array}{l}196 \\
(51)\end{array}$ & $\begin{array}{l}144 \\
(36)\end{array}$ & $\begin{array}{c}493 \\
(0.61) \\
\end{array}$ & $\begin{array}{c}307 \\
(0.39) \\
\end{array}$ \\
\hline $\begin{array}{c}\text { Total patients } \\
(\mathrm{n}=405)\end{array}$ & $\begin{array}{c}52 \\
(13) \\
\end{array}$ & $\begin{array}{l}204 \\
(50) \\
\end{array}$ & $\begin{array}{l}149 \\
(37) \\
\end{array}$ & $\begin{array}{c}502 \\
(0.62) \\
\end{array}$ & $\begin{array}{c}308 \\
(0.38) \\
\end{array}$ \\
\hline $\begin{array}{c}\text { Psor. Vulgaris } \\
(\mathrm{n}=324)\end{array}$ & $\begin{array}{l}30 \\
(9)\end{array}$ & $\begin{array}{l}157 \\
(49)\end{array}$ & $\begin{array}{l}137 \\
(42)\end{array}$ & $\begin{array}{c}431 \\
(0.67)\end{array}$ & $\begin{array}{c}217 \\
(0.33)\end{array}$ \\
\hline $\begin{array}{l}\text { Familial Ps } \\
(n=221)\end{array}$ & $\begin{array}{c}32 \\
(14)\end{array}$ & $\begin{array}{l}113 \\
(51)\end{array}$ & $\begin{array}{c}76 \\
(34)\end{array}$ & $\begin{array}{c}265 \\
(0.60)\end{array}$ & $\begin{array}{c}177 \\
(0.40)\end{array}$ \\
\hline $\begin{array}{l}\text { Sporadic Ps } \\
(\mathrm{n}=184)\end{array}$ & $\begin{array}{c}20 \\
(11)\end{array}$ & $\begin{array}{c}91 \\
(50)\end{array}$ & $\begin{array}{c}73 \\
(39)\end{array}$ & $\begin{array}{l}237 \\
(0.64)\end{array}$ & $\begin{array}{l}131 \\
(036)\end{array}$ \\
\hline $\begin{array}{c}\text { Early onset Ps } \\
(n=243)\end{array}$ & $\begin{array}{c}32 \\
(13)\end{array}$ & $\begin{array}{l}124 \\
(51)\end{array}$ & $\begin{array}{c}87 \\
(36)\end{array}$ & $\begin{array}{c}298 \\
(0.61)\end{array}$ & $\begin{array}{c}188 \\
(0.39)\end{array}$ \\
\hline $\begin{array}{l}\text { Late onset Ps } \\
\quad(n=162)\end{array}$ & $\begin{array}{c}20 \\
(12)\end{array}$ & $\begin{array}{l}77 \\
(48)\end{array}$ & $\begin{array}{l}65 \\
(40)\end{array}$ & $\begin{array}{l}207 \\
(0.64)\end{array}$ & $\begin{array}{c}117 \\
(0.36)\end{array}$ \\
\hline $\begin{array}{c}\text { Non Severe Ps } \\
(n=243)\end{array}$ & $\begin{array}{c}28 \\
(11)\end{array}$ & $\begin{array}{l}126 \\
(52)\end{array}$ & $\begin{array}{c}89 \\
(37)\end{array}$ & $\begin{array}{c}304 \\
(0.63)\end{array}$ & $\begin{array}{c}182 \\
(0.37)\end{array}$ \\
\hline $\begin{array}{l}\text { Severe Ps } \\
(n=162)\end{array}$ & $\begin{array}{c}24 \\
(15)\end{array}$ & $\begin{array}{c}78 \\
(48)\end{array}$ & $\begin{array}{c}60 \\
(37)\end{array}$ & $\begin{array}{c}198 \\
(0.61)\end{array}$ & $\begin{array}{c}126 \\
(0.39) \\
\end{array}$ \\
\hline $\begin{array}{l}\text { Arthritis } \\
(\mathrm{n}=83)\end{array}$ & $\begin{array}{c}8 \\
(10)\end{array}$ & $\begin{array}{c}49 \\
(59)\end{array}$ & $\begin{array}{c}26 \\
(31)\end{array}$ & $\begin{array}{c}101 \\
(0.61)\end{array}$ & $\begin{array}{c}65 \\
(0.39)\end{array}$ \\
\hline $\begin{array}{l}\text { Non arthritis } \\
(n=322)\end{array}$ & $\begin{array}{c}44 \\
(14)\end{array}$ & $\begin{array}{l}155 \\
(45)\end{array}$ & $\begin{array}{l}123 \\
(41)\end{array}$ & $\begin{array}{c}401 \\
(0.62)\end{array}$ & $\begin{array}{c}243 \\
(0.38)\end{array}$ \\
\hline $\begin{array}{c}\text { Cw6 positive } \\
(n=158)\end{array}$ & $\begin{array}{l}11 \\
(8)\end{array}$ & $\begin{array}{c}81 \\
(51)\end{array}$ & $\begin{array}{c}66 \\
(42)\end{array}$ & $\begin{array}{c}213 \\
(0.67)\end{array}$ & $\begin{array}{c}103 \\
(0.33)\end{array}$ \\
\hline $\begin{array}{c}\text { Cw6 negative } \\
(\mathrm{n}=247)\end{array}$ & $\begin{array}{c}40 \\
(16)\end{array}$ & $\begin{array}{l}123 \\
(50)\end{array}$ & $\begin{array}{c}84 \\
(34)\end{array}$ & $\begin{array}{c}291 \\
(0.59)\end{array}$ & $\begin{array}{c}203 \\
(0.41)\end{array}$ \\
\hline $\begin{array}{l}\text { Psor. Vulgaris } \\
\text { Non arhritis } \\
(n=274)\end{array}$ & $\begin{array}{l}25 \\
(9)\end{array}$ & $\begin{array}{l}128 \\
(47)\end{array}$ & $\begin{array}{l}121 \\
(44)\end{array}$ & $\begin{array}{c}370 \\
(0.68)\end{array}$ & $\begin{array}{c}178 \\
(0.32)\end{array}$ \\
\hline
\end{tabular}

patients and a control/patient ratio of 1.46, a total of 1,154 controls and 938 patients should be genotyped to reach a power of 80 (\% chance of detecting).

\section{SNP rs4112788 genotype frequencies}

SNP rs4112788 in the LCE3D gene was genotyped in all the patients and controls through PCR-RFLP (Figure 1). This polymorphism maps approximately $4.5 \mathrm{~Kb}$ centromeric to the LCE3C_LCE3B-del, and allele C has been reported in almost complete linkage disequilibrium (LD) with the deletion. In agreement with this, all our patients and controls who were homozygous for the deletion were also rs4112788 CC, while all the non-deletion homozygotes were also TT. All but two ins/del individuals were also CT (one patient and one control were $\mathrm{CC}$ ). To determine the accuracy of the PCR-RFLP method, we first sequenced 60 individuals, 20 each of the three genotypes. We confirmed the genotype in all the 60 samples, and we also found a complete disequilibrium between rs4112788 and rs4112787 (T/C), a SNP located $49 \mathrm{bp} \mathrm{3'}$ to rs4112788. A total of 100 patients and 100 controls were also genotyped with a custom Taqman assay (Figure 2). We only found one discrepancy between the RFLP and Taqman methods: one patient genotyped as TC with the PCR-RFLP method was $\mathrm{CC}$ according to the Taqman assay, and sequencing confirmed the RFLP genotype. Thus, the accuracy of our PCR-RFLP genotyping method should be almost complete.

\section{Mutation analysis of $\angle C E 3 B$ and $\angle C E 3 C$}

We searched for DNA variants in the $L C E 3 B$ and $L C E 3 C$ coding sequences in the patients. After electrophoresis of the PCRs, a band was only visible in the 353 patients with at least one copy of LCE3C_LCE3B. This result confirmed the absence of the two LCE3C_LCE3B copies in the 149 patients who were genotyped as homozygotes for the deletion. The sequencing of 45 chromosomes (15 ins/ins and 15 ins/del patients) showed no nucleotide variants in the two genes. SSCA and DHPLC indicated the absence of nucleotide changes in all the $L C E 3 C$ PCR-fragments. Only one patient showed an $L C E 3 B$ heterogeneous SSCA/DHPLC pattern (Figure 3). After sequencing, we found that this individual (a 28 year-old patient with chronic plaque type Ps without arthritis and heterozygous for the deletion) had a missense change: R68C (CGC>TGC). We did not find this nucleotide change in the 400 controls (genotyped through SSCA).

\section{Discussion}

SNP rs4112788 and the LCE3C_LCE3B-del have been associated with Ps $[9,17,20]$. In their analysis of 1,425 patients and 1,406 controls from four different populations, De Cid et al. found a significantly higher frequency of del/del homozygotes among the patients (total del/del frequency, 0.45 in patients vs. 0.34 in controls; $\mathrm{OR}=2.04,95 \% \mathrm{CI}=1.59-2.62, \mathrm{p}=1.71 \mathrm{e}-08)$. This was further confirmed by Hüffmeier et al. in individuals of German origin [15]. We did not find this difference when all the Ps patients were compared to controls. However, in agreement with these authors the del/del genotype was more frequent among patients with psoriasis vulgaris, although our OR was lower and did not reach statistical significance, probably due to the limited sample size $[9,15]$.

Huffmeier et al. reported a lack of association between the LCE3C_LCE3B-del and PsA among German patients [16]. We found a lower frequency of del/del among the patients who developed arthritis, compared to patients with only skin disease. Moreover, when patients with Ps vulgaris and without joint manifestations were compared to controls, we found a significantly higher frequency of the del/del genotype. This confirmed the reported association of this marker with only skin disease $[15,16]$. 


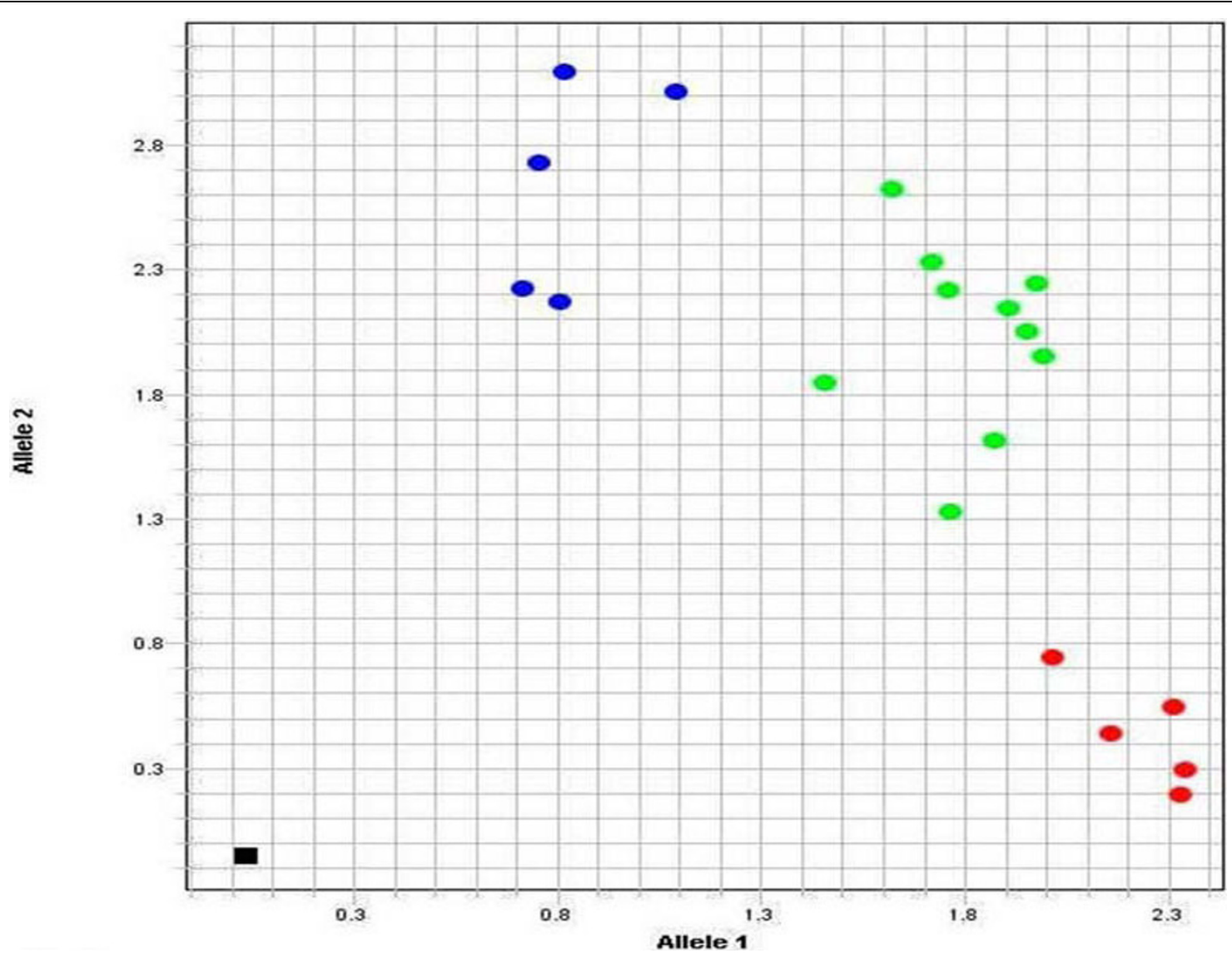

Figure 2 Taqman genotyping of SNP rs4112788 in 20 individuals, 5 CC (blue dots), 10 CT (green dots), and 5 TT (red dots). The black spot in the down-left was the negative control.

The association between the LCE3C_LCE3B-del and Ps vulgaris was weaker in our population compared to the reported by others. This is illustrated by the fact that for an OR of 1.46 and a $\mathrm{p}=0.05$ at least 1,154 patients (Ps vulgaris without joint disease) and 938 controls should be genotyped to reach a power of 80 . This discrepancy with other studies could be partly attributed to differences in the main characteristics of patients and controls. De Cid et al. analysed a total of 175 patients and 382 healthy controls from a different Spanish region [9]. The deletion allele had almost the same frequency in their patients (0.64) and ours (0.62), and the significant risk for Ps was due to a lower frequency of the deletion among their controls (0.55 vs. 0.61). The lower association in our study could be thus attributed to differences in the criteria followed by the recruitment of these controls. However, this is unlikely because controls in the two studies were healthy individuals from the general population and with similar mean age. Mistyping of the LCE3C_LCE3B alleles in some of our patients and controls could also explain the results, but

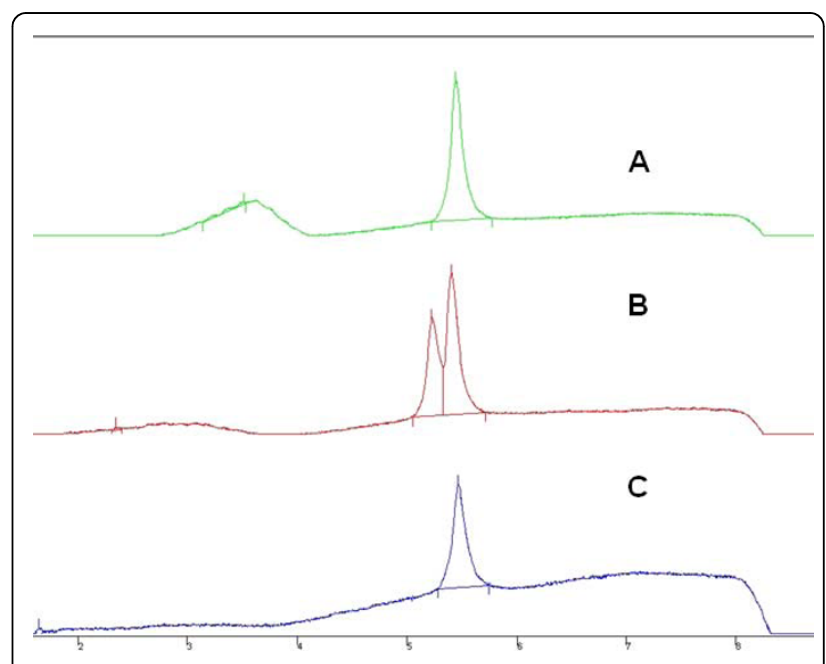

Figure 3 DHPLC profiles of three LCE3B-PCR fragments. The normal sequences gave a single elution peak, while the fragment with a nucleotide change eluted as a double peak (B). Fragments were eluted with the universal gradient of Varian Helix buffers $A$ and B http://www.varianinc.org/, and at a temperature of $60^{\circ} \mathrm{C}$. 
this was also unlikely because we found an identical degree of association with rs4112788, a SNP in almost complete LD with the LCE3C_LCE3B-del. Moreover, the genotype frequencies in our patients and controls were in Hardy-Weinberg equilibrium, suggesting they were representative of the general population.

Differences in the main clinical characteristics of the patients could also explain the lack of association in our study. Compared to others, our work included patients with a higher mean age, and a lower proportion of familial and severe cases. This could explain the low frequency of $\mathrm{Cw} 6+$ among our cases, a marker reported to be more common among severe earlyonset Ps [21]. The frequency of this marker was also more frequent among our patients with familial and early-onset Ps. In this way, the effect of the deletion allele on Ps-risk could be higher in patients with an early onset, familial, and severe disease, and this could result in a reduced frequency of LCE3B_LCE3C-del among our cases.

Finally, the analysis of $L C E 3 B$ and $L C E 3 C$ coding sequences in cases with at least one copy of these genes showed that only one patient had a missense change at a conserved $L C E 3 B$ amino acid $(\mathrm{R} 68>C)$. This was not found in the controls. SSCA and DHPLC are indirect techniques to detect nucleotide changes in PCR fragments and, although they have a low rate for false negatives, we cannot exclude that some of the patients harbour non identified mutations.

\section{Conclusions}

Our work suggested that individuals homozygous for the LCE3C_LCE3B-del are at risk of developing Ps vulgaris without arthritis manifestation. This confirmed the recently reported association between this marker and only skin psoriasis, reinforcing the concept of Ps as a deregulation in the wound response programs.

\section{Author details \\ ${ }^{1}$ Genética Molecular, Hospital Universitario Central Asturias-Servicio de Salud del Principado de Asturias, Oviedo, Spain. ${ }^{2}$ Unidad Dermatología II, Hospital Universitario Central Asturias-Servicio de Salud del Principado de Asturias, Oviedo, Spain. ${ }^{3}$ Servicio de Reumatología, Hospital Universitario Central Asturias-Servicio de Salud del Principado de Asturias, Oviedo, Spain. \\ ${ }^{4}$ Department of Medicine, University of Oviedo, Oviedo, Spain.}

\begin{abstract}
Authors' contributions
EC, JSJ, and VA designated the work, analyzed the results, and wrote the manuscript. JSJ, PCS, JS, and RQ recruited the patients and controls and obtained the clinical, analytical and anthropometric data. EC, MD, and VA performed the genetic studies. All the authors revised and approved the final version of the manuscript.
\end{abstract}

\section{Competing interests}

The authors declare that they have no competing interests.
References

1. Christophers E: Psoriasis: epidemiology and clinical spectrum. Clin Exp Dermatol 2001, 26:314-320.

2. Krueger JG, Bowcock A: Psoriasis pathophysiology: current concepts of pathogenesis. Ann Rheum Dis 2005, 64:Sii30-36.

3. Helliwell PS, Taylor WJ: Classification and diagnostic criteria for psoriatic arthritis. Ann Rheum Dis 2005, 64:ii3-ii8.

4. Bowcock AM, Cookson WO: The genetics of psoriasis, psoriatic arthritis and atopic dermatitis. Hum Mol Genet 2004, 13:R43-R55.

5. Russell TJ, Schultes LM, Kuban DJ: Histocompatibility (HL-A) antigens associated with psoriasis. N Engl J Med 1972, 287:738-740.

6. Nair RP, Stuart PE, Nistor l, et al: Sequence and haplotype analysis supports HLA-C as the psoriasis susceptibility 1 gene. Am J Hum Genet 2006, 78:827-51.

7. Liu Y, Helms C, Liao W, Zaba LC, Duan S, Gardner J, Wise C, Miner A, Malloy MJ, Pullinger CR, Kane JP, Saccone S, Worthington J, Bruce I, Kwok PY, Menter A, Krueger J, Barton A, Saccone NL, Bowcock AM: A genome-wide association study of psoriasis and psoriatic arthritis identifies new disease loci. PLoS Genet 2008, 4:e1000041.

8. Nair RP, Duffin KC, Helms C, Ding J, Stuart PE, Goldgar D, Gudjonsson JE, Li Y, Tejasvi T, Feng BJ, Ruether A, Schreiber S, Weichenthal M, Gladman D, Rahman P, Schrodi SJ, Prahalad S, Guthery SL, Fischer J, Liao W, Kwok PY, Menter A, Lathrop GM, Wise CA, Begovich AB, Voorhees JJ, Elder JT, Krueger GG, Bowcock AM, Abecasis GR: Collaborative Association Study of Psoriasis. Genome-wide scan reveals association of psoriasis with IL-23 and NF-kappaB pathways. Nat Genet 2009, 41:199-204.

9. de Cid R, Riveira-Munoz E, Zeeuwen PL, Robarge J, Liao W, Dannhauser EN, Giardina E, Stuart PE, Nair R, Helms C, Escaramís G, Ballana E, MartínEzquerra G, den Heijer M, Kamsteeg M, Joosten I, Eichler EE, Lázaro C, Pujol RM, Armengol L, Abecasis G, Elder JT, Novelli G, Armour JA, Kwok PY, Bowcock A, Schalkwijk J, Estivill X: Deletion of the late cornified envelope LCE3B and LCE3C genes as a susceptibility factor for psoriasis. Nat Genet 2009, 41:211-215.

10. Cargill M, Schrodi SJ, Chang M, Garcia VE, Brandon R, Callis KP, Matsunami N, Ardlie KG, Civello D, Catanese JJ, Leong DU, Panko JM, McAllister LB, Hansen CB, Papenfuss J, Prescott SM, White TJ, Leppert MF, Krueger GG, Begovich AB: A large-scale genetic association study confirms IL12B and leads to the identification of IL23R as psoriasis-risk genes. Am J Hum Genet 2007, 80:273-290.

11. Estivill $X$, Armengol L: Copy number variants and common disorders: filling the gaps and exploring complexity in genome-wide association studies. PLOS Genet 2007, 3:1787-1799.

12. Hollox EJ, Huffmeier U, Zeeuwen PL, Palla R, Lascorz J, Rodijk-Olthuis D, Kerkhof van de PC, Traupe H, de Jongh G, den Heijer M, Reis A, Armour JA, Schalkwijk J: Psoriasis is associated with increased beta-defensin genomic copy number. Nat Genet 2008, 40:23-25.

13. Jackson B, Tilli CM, Hardman MJ, Avilion AA, MacLeod MC, Ashcroft GS, Byrne C: Late cornified envelope family in differentiating epitheliaresponse to calcium and ultraviolet irradiation. J Invest Dermatol 2005, 124:1062-1070.

14. Capon F, Novelli G, Semprini S, Clementi M, Nudo M, Vultaggio P, Mazzanti C, Gobello T, Botta A, Fabrizi G, Dallapiccola B: Searching for psoriasis susceptibility genes in Italy: genome scan and evidence for a new locus on chromosome 1. J Invest Dermatol 1999, 112:32-35.

15. Hüffmeier U, Estivill X, Riveira-Munoz E, Traupe H, Wendler J, Lohmann J, Böhm B, Burkhardt H, Reis A: Deletion of LCE3C and LCE3B genes at PSORS4 does not contribute to Susceptibility to Psoriatic Arthritis in German patients. Ann Rheum Dis 2009.

16. Hüffmeier U, Bergboer JG, Becker T, Armour JA, Traupe H, Estivill X, RiveiraMunoz E, Mössner R, Reich K, Kurrat W, Wienker TF, Schalkwijk J, Zeeuwen PL, Reis A: Replication of LCE3C-LCE3B CNV as a Risk Factor for Psoriasis and Analysis of Interaction with Other Genetic Risk Factors. J Invest Dermatol 2010, 130:979-984.

17. Fredriksson T, Petterson U: Severe Psoriasis-Oral therapy with a new retinoid. Dermatologica 1978, 157:238-244.

18. Moll JMH: Psoriatic arthropaty. Textbook of Dermatology Edinburgh: Churchill LivingstonMier PD, van der Kerkof PCM 1986, 55-82.

19. González P, García-Castro M, Reguero JR, Batalla A, Ordóñez AG, Palop RL, Lozano I, Montes M, Alvarez V, Coto E: The Pro279Leu variant in the transcription factor MEF2A is associated with myocardial infarction. J Med Genet 2006, 43:167-169. 
20. Zhang XJ, Huang W, Yang S, Sun LD, Zhang FY, Zhu QX, Zhang FR,

Zhang C, Du WH, Pu XM, Li H, Xiao FL, Wang ZX, Cui Y, Hao F, Zheng J,

Yang XQ, Cheng H, He CD, Liu XM, Xu LM, Zheng HF, Zhang SM, Zhang JZ,

Wang HY, Cheng YL, Ji BH, Fang QY, Li YZ, Zhou FS, Han JW, Quan C,

Chen B, Liu JL, Lin D, Fan L, Zhang AP, Liu SX, Yang CJ, Wang PG,

Zhou WM, Lin GS, Wu WD, Fan X, Gao M, Yang BQ, Lu WS, Zhang Z,

Zhu K, Shen SK, Li M, Zhang XY, Cao TT, Ren W, Zhang X, He J, Tang XF,

Lu S, Yang JQ, Zhang L, Wang DN, Yuan F, Yin XY, Huang HJ, Wang HF,

Lin $X Y$, Liu JJ: Psoriasis genome-wide association study identifies

susceptibility variants within LCE gene cluster at 1q21. Nat Genet 2009,

41:205-210.

21. Martínez-Borra J, Gonzalez S, Santos-Juanes J, Sanchez del Rio J, Torre-

Alonso JC, Lopez-Vazquez A, Blanco-Gelaz MA, Lopez-Larrea C: Psoriasis vulgaris and psoriatic arthritis share a $100 \mathrm{~kb}$ susceptibility region telomeric to HLA-C. Rheumatology 2003, 42:1089-1092.

\section{Pre-publication history}

The pre-publication history for this paper can be accessed here:

http://www.biomedcentral.com/1471-2350/11/45/prepub

doi:10.1186/1471-2350-11-45

Cite this article as: Coto et al:: Mutation analysis of the LCE3B/LCE3C

genes in Psoriasis. BMC Medical Genetics 2010 11:45.

\section{Submit your next manuscript to BioMed Central} and take full advantage of:

- Convenient online submission

- Thorough peer review

- No space constraints or color figure charges

- Immediate publication on acceptance

- Inclusion in PubMed, CAS, Scopus and Google Scholar

- Research which is freely available for redistribution

Submit your manuscript at www.biomedcentral.com/submit 